Port Econ J (2014) 13:131-140

DOI 10.1007/s10258-014-0102-X

\title{
Product market competition with differentiated goods and social welfare in the presence of an industry-wide union
}

Domenico Buccella

Received: 12 July 2013 / Accepted: 15 May 2014 / Published online: 21 June 2014 \# ISEG 2014

\begin{abstract}
Mainstream locus communis indicates that a more competitive product market leads to higher social welfare levels. Using a Conjectural Variation (CV) model, this research note analyzes the effects on welfare of different degrees of product market competition in a duopoly with differentiated goods. Bargaining between the firms and the industry-wide union occurs under the Efficient Bargaining (EB) model. The work indicates that, with close substitute goods, social welfare is maximized for the intermediate levels of market competition, whereas more independent goods lead to the standard result of a high welfare level under competitive markets.
\end{abstract}

Keywords Bargaining · Conjectural variation · Unionized oligopoly · Social welfare

JEL Classification $\mathrm{D} 43 \cdot \mathrm{J} 51 \cdot \mathrm{L} 13$

D. Buccella

Department of Economics, Kozminski University, Jagełłonska Street, 57/59, Warsaw 03301, Poland e-mail: buccella@kozminski.edu.pl 